\title{
Analysis of Game of Thrones Series from Freudian Perspective
}

\author{
Övür A. ${ }^{1}$ \\ ${ }^{1}$ Ayten ÖVÜR, İstanbul Aydın University, (Turkey) \\ e-mail: aytenovur@aydin.edu.tr
}

\begin{abstract}
Game of Thrones series, which can be regarded as a game played upon repressed instincts of human, trails a large audience due to its impressive scenes supported with music, costumes and effects. The series, which was fictionalized based on various instincts that Freud greatly mentioned in his books turned into an environment on which inexpressible stories were told and taboos were shaken. Which kind of effects that revitalizing, unveiling and disclosing these instincts could have is a question that needs to be considered. The objective of this study, which was conducted using the content analysis method, is to reveal the methods used to attract audience on one of the popular series in the present day, Game of Thrones, and to draw attention to games played on human subconscious.
\end{abstract}

Keywords: Freud, Game of Thrones, Instinct, Series, Subconscious.

\section{Introduction}

Young people spend most of their time and almost all of their leisure time on internet environment in today's media era. They mostly spend their time on digital games, social media, and internet series. Therefore, communication studies, cultural studies and new media studies focus on these subjects and address them from different perspectives. This study aimed to examine the content of Game of Thrones, which is the most-watched series on online and has a major audience worldwide, from Freudian perspective.

Contents presented on media changes based on time, political, social and economic conditions. "Media is defined as techno-social systems on which technological structures interact with social relationships and human activities in a complex way" (Fuchs, 2016: 72). Castells mentions that today's Internet is shaped based on the conflict between the global multimedia commercial networks which try to commodify Internet and the "creative audience" which tries to form a citizen' control level on Internet and supports the freedom of communication right without a commercial control (Fuchs, 2016: 107). New media, which is discussed on philosophic, cultural, ideological, sociological and economic platforms is a technology-based and -supported concept. The new media should be assessed with consumption culture, culture industry and globalization (Ormanlı, 2012: 340).

Studies on uses and gratifications which present key structures for the examination of audience reaction focuses especially on media consumption. The focus on the question of what people do with media rather than what media do to people. What people do with new media on their free time which transformed into digital gains prominence within this question? With the use of new media, the concept of watching a TV series transforms and as a part of this transformation, people adopt to the concept of binge watching. Rather than waiting for episodes, saving them for later and watching them one after the other become popular. This changing new method of watching TV series has occurred based on people's desire to control what they watch, where and when they watch and how they watch. In the USA, habits of watching TV series changes as people easily access to websites such as Netflix, Hulu and Amazon Instant Video through which they can consecutively watch series and films and tools such as Apple TV and Amazon Fire TV. The concept of "binge watching" which occurred through these possibilities is defined as "watching videos and TV series for a specific 
time non-stop." Rather than waiting for a week to watch a new episode, followers of TV series can access to whichever episode they want through these platforms at any time (Yengin, 2015: 217-249).

Moreover, websites such as dizibox, diziyo and dizilab that give online access to TV series are in great demand in Turkey. It became possible to watch a series one after another without leaving the computer or through a smart phone whereever you want. Game of Thrones series, which is one of the most preferred series and has broken records since it has been aired for the first time in 2011, was chosen as the subject of this study based on the fact that it has affected millions of people worldwide, included different contents, reflected subjects that are thought to be taboo and included pervert characters. This study examined this series in terms of psychology and communication science with an interdisciplinary approach.

\section{Game of Thrones Series}

Game of Thrones is a fantastic TV series and created by David Benioff and Daniel Brett Weiss. It is aired by HBO, a USA-based TV channel. It was adapted from the epic fantasy series of George R. R. Martin, "A Song of Ice and Fire" and named with the first book of this series. The TV series was filmed in Northern Ireland, Malta, Croatia, Morocco, and in a studio in Belfast. The first episode was aired on April 17, 2011 on HBO and the final season of it, 8th season, has been aired on 2019.

Ratings of Game of Thrones in the USA has increased per annum. The final episode of the 7th season of the series named "The Dragon and the Wolf" which was lasted 80 minutes was watched by 12.1 million audience during the time it was aired in the USA. The number of live audience reaches to 16.5 after adding the number of audience watching the episode on HBO Now and HBO Go. The same episode was reported to watch by 31 million in total. It is not possible to determine the total number of audiences of the series which was aired on 170 countries (url1). Official rating record in the USA gives an idea on the increasing number of audience.

\begin{tabular}{|l|}
\hline $\begin{array}{l}\text { The number of audience in the USA is as follows: (Official rating records } \\
\text { without counterfeit rating) }\end{array}$ \\
\hline Game of Thrones Season 1 (2011)-9.3 million \\
\hline Game of Thrones Season 2 (2012)-11.6 million \\
\hline Game of Thrones Season 3 (2013)-14.2 million \\
\hline Game of Thrones Season 4 (2014)-18.6 million \\
\hline Game of Thrones Season 5 (2015)-20 million \\
\hline Game of Thrones Season 6 (2016)-23 million \\
\hline
\end{tabular}

Table 1. The number of audiences in the USA (url1)

The series has a fascinating subject enriched with sub-stories. The world in the series has mysterious creatures living on it and seasons with changing duration, thus making it different from the real world. The setting of the series which is called Seven Kingdom of Westeros has various regions and each of them is governed by different houses (royal families). Lords leading these families are in a great war of power among themselves; however, they are loyal to the King, who has been chosen as the ruler of Westeros, and Iron Throne. The names of the houses are as follows: House Arryn, House Baratheon, House Greyjoy, House Lannister, House Martell, House Stark, House Targaryen, House Tully and House Tyrell (url2).

The summary of the series is as follows: Aerys II Targaryen, also known as the Mad King, of the House Targaryen gets dethroned through a rebellion. Robert of the House Baratheon gets crowned and becomes the new ruler of the Seven Kingdom. Robert asks the help of Eddard Stark, the lord of Winterfell and his close friend, because of a mysterious murder occurred during his reign. Stark agrees to help the King to protect the Iron Throne against complex intrigues. He finds out that the King's children are illegitimate, thus becomes the target of Queen Cersei Lannister. Cersei plans the death of the King and Eddard Stark to protect and enthrone her children whose father is Cersei's twin 
brother. In the meantime, the army of the dead gathers beyond the enormous Wall, which is on the northernmost point of Winterfell. John Snow, the illegitimate son of Stark, battles against the army of dead. Also, Targaryen siblings who are from the lineage of Dragon-kings make plans to get the throne back through the dragon eggs (url3). The children of Eddard Stark, who was shown as a main character in the first episodes, fall apart with the death of their father and their stories are told throughout numerous episodes. In the seventh season, John Snow, who was known as the illegitimate son of Eddard Stark, is revealed to be the legitimate son of Rhegar Targaryen and Lyanna Stark and the true heir of the throne. One of the most important characters in the series, Khaleesi/Daenerys Targaryen is a powerful female character fighting for the throne with her three dragons which grow day by day. Unaware of his true identity, John Snow crosses paths with Khaleesi while seeking help for battling the army of dead and has a love affair with her, his father's sister.

Although it has contents that can never be aired on Turkish television channels, Game of Thrones series attracts intensive attention in Turkey through the accessibility of new media tools. Popularity of the series increased with the posts shared on social media and it became one of the most-watched series. Game of Thrones has revealed and normalized the repressed instincts of humans and raised these instincts up to consciousness by triggering them. This series has addressed and awakened the instincts that according to Freud, people gave up because of culture and civilization, and this indicates that either the writers examined these instincts and read Freud deeply or they tried to increase ratings by presenting different things.

\section{Violence, Death, Murder and Sexual Instincts}

In general, our civilization has been built upon repressing humane instincts. Each individual gave up on a part of their existence, the feeling of omnipotence, aggression or revenge tendencies of their personality. This renunciation has increased during the evolution of the civilization. A person who does not comply with this instinctual repression is regarded as a "criminal" by the society (Freud, 2007a: 36).

Freud discussed the antagonism between civilization and instinctual life and stated that all civilizations force individuals to work and make instinctual sacrifices (Freud, 2017a: 33). According to Freud, it is not possible to disregard the fact that civilization is built upon the sacrifices from instincts and the extent of this. Civilization has been formed under the pressure of life necessities and at the risk of not satisfying our instincts. For example, aggression is an independent and instinctual habit which is a part of human nature (Freud, 2017b: 44-56). Culture overcomes individuals' pleasure of aggression by weakening the pleasure, "disarming them and by keeping a close eye on them just like occupation forces in an invaded city do through an authority within them" (Freud, 2016g: 52). Today's civilized societies try to suppress, demolish and tame various instincts such as aggression tendencies through strict laws, religious rules and education. However, there is a possibility of instantaneous appearance of these just like any other repressed things. Numerous studies have examined the effects of media contents (series, films, digital games, news, etc.) that trigger these emotions on people, and various approaches have been determined.

One of these approaches is the theory of catharsis which states that aggression can be diminished by expressing or releasing it. Freud addressed this theory as a concept of psychology, emotional catharsis on aggression. Freud stated that "As long as people have someone to direct their aggression on, it is possible to connect numerous people together through attachment of love"** (2017b: 54). According to the "Theory of Offensive Examples", audience resort to violence which they have within themselves on real life after using the TV program which includes violence as a catalyst. Audience uses violence they saw on TV just like children who learn by imitating their parents' behaviors. Especially young people link the feeling of violence within themselves with bad characters in films and TV series that they watch, and they resort to imitate these. According to the "Mean World Syndrome" theory of George Gerbner, the images of violence supports people's belief that the world outside brutal rather than resorting audience to violence. This approach indicates that audience gets affected from the scenes with violence, murder, injustice, purse snatching, cheating and rape, and is of the opinion that the real world is much more brutal than the world shown on TV; therefore, prefers to

\footnotetext{
* This statement of Freud is explanatory for politicians' efforts to bring people together by creating a mutual enemy for propaganda.
}

DOI NO: 10.7456/ctc_2019_03 
stay at home and watch television rather that exploring the real world. This profile of audience is what the television producers are looking for. Because the longer the audience sits in front of the TV the higher the ratings get (Koç, 2018: 30-32). Moreover, some authorities look for this profile of audience, who are passive, only take what is given, are not interested in world-related things, spend time on media contents and do not question, as they are easy to manage and lead. The researchers focused on the following questions; which one of these theories should be taken as base? Which theory applies for which situation? Do violent images affect everyone in the same way? Or what kind of people gets affected by them more?

The death instinct was suggested by Freud. According to Freud, "No one believes to their own death. In the unconscious, everyone is convinced that they are immortal." (2017b: 10) and in 1914, he claimed that people/ego whose narcissism is harmed due to the obligation of death try to guarantee their immortality by having children. Freud published a study named the "Ideas on War and Death" in 1915 and made inferences on the place of death on human experience. Basically, Freud's claim states that in the unconscious, everyone believes that we are immortal as we cannot imagine and know death (Şensoy, 2015: 1). In 1920, Freud suggested the death instinct as oppose to the life instinct. Thus, the old life instinct theory gave way to a dualist instinct theory (Freud, 2016f: 408).

Freud explains the death instinct as individuals' tendency towards self-destruction and transforming back to anorganic status. Aggression is the externalized form of the death instinct in a dualistic way. Freud proposed that "The goal of all life is death." and regarded death as an impulse/instinct like life. According to Freud, the life instincts (Eros) include activities that aim selfprotection and continuation of the species such as hunger, thirst and sexuality. These creative powers and energies that are revealed through libido ensure the continuation of life. On the other hand, the death instincts (Thanatos) are destructive. It can be intrinsic just like in masochism and suicide or extrinsic just like aggression and hatred. Freud believes that people irresistibly proceed to death (quoted by Yılmaz from Schultz \& Schultz, 2013: 174).

Normally, Eros and Thanatos coexist in a balanced way. However, this coexistence dissolves in the case of pathological situations such as self-punisher tendencies of sadist or melancholic people (Freud, 2016f: 408). Sadism involves using violence or force on another person as the object (Freud, 2000: 93). The only purpose of all hot-blooded sexual desires of sadists is to abuse or torture the sexual object. Such torture may vary from insulting and humiliating the sexual object to physically harming them in a very severe way (Freud, 2016a: 103).

According to Freud, sex life of human has been damaged and he stated that sex life of human gives the impression of a function that regresses just like our teeth and hair on our head which can be regarded as human organs (Freud, 2016g: 53). The fact that humans and animals have sexual needs is defined with the hypothesis of "sexual instinct" by making an analogy with biology, in other words, the instinct of hunger. Although there is no expression that gives the meaning of "hunger" in daily language, the term "libido" is used for this meaning in the scientific jargon (Freud, 2016e: 49). Sexual instincts are regarded as instincts that can be changed and adapted to life. According to Fromm, there are some characteristics that differentiate these from self-protection instincts. For example, sexual instincts can be postponed different from self-protection instincts. Self-protection instincts are more coercive because if not satisfied for a long time, it will result in death. Concisely, postponing the satisfaction for a long time cannot be psychologically tolerated. This means that self-protection instincts take precedence of sexual instincts (Fromm, 2004a: 55). However, sexual instincts can be repressed or diverted to another direction. In other words, rather than directly satisfying, a sexual desire can be combined with another activity of ego by deviating from the sexual aim of it. In general, sexual urges can only be satisfied with fantasies (Fromm, 2004a: 56 ).

Sexual instincts can be used for various civilization goals and can contribute to the success of civilization because they can influence people and distort people's goals (Freud, 2016f: 124). However, this does not mean that they can always be abandoned. Sexual instincts should at least be satisfied at a minimum level (Fromm, 2004a: 56). According to Freud, it is quite hard to think of an artist following a sexual diet; however, a young scholar following a diet is not a rare situation. Scholars can focus their energy on their studies by restricting themselves; however, artists can observe that sexual experiences enhance their artistic success. Freud stated that in general, sexual diet does not create energetic, self-confident men of action, authentic philosophers or brave reformists; rather than 
in most cases the diet later on transforms powerful individuals into good natured and weak people who display follow-up tendencies and who disappear within the masses (Freud, 2007a: 46).

Sexual object is defined as the person to whom sexual pull subjected (desired), and sexual aim is defined as the action to which the instincts directed. Scientifically strained observations have shown various deviations for both of them (Freud, 2016e: 50). Instincts which cause the development of hysteric symptoms draw their strength both from repressed normal sexuality and subconscious aberrant activities (Freud, 2017d: 45). The concept of Oedipus complex shows how the most universal themes of all the human instincts investigated by psychoanalysis and the conflicting human reality which is regarded as universal such as sexuality, aggression, jealousy, rivalry, revenge, fear of vengeance, love, morality, incest taboo, etc. gang up on early mother-father-child triangle (Freud, 2016b: 12). Later on, the Oedipus complex becomes the keystone of Freudian psychology. Freud saw this as a key that explains the development of religion and morality and suggested that this complex has an important role on child development. He thought that the Oedipus complex formed the base of psychopathological development and the "core of neurosis" (Fromm, 2003: 191).

According to Fromm, this myth is not the symbol of incest love between a mother and her son; King Oedipus symbolizes a man who has won a victory against his father. It is a rebellion against the authority of father in the patriarchal family. The characters of Sophocles, Oedipus, Haimon and Antigone represent the matriarchal principle. All three of them go against the social and religious orders of their fathers. Fromm builds these interpretations upon Bachofen's analysis of Greek Mythology. Bachofen examined religious documents which belonged to Greek and Roman antiquities and noticed that women had a pioneering role on family and society along with religion. Additionally, Bachofen proved that a Mother Goddess and a religion based on heroines existed. According to Bachofen, men defeated women and took women under their domination over time; in addition, they formed a patriarchal social order. The Mother Goddess was replaced by a male God (Fromm, 2003: 194-197).

Matriarchal principles can be summarized as blood relation, tradition, unconditional love and giving. This understanding only regards natural and biological things as valuable. On the other hand, patriarchal principles focus on intelligence, discipline and abstract thoughts. "Today's social structures which based on authority and system of exploitation emerged as a result of the union of patriarchal principles and capitalist understanding." Patriarchal social structure strictly depends on class characteristics of today's society in terms of psycho-social bases. Society is shaped by specific psychological behaviors arising from subconscious instincts to a certain extent, and psychological behaviors effectively determine the restraint that governing tool has on society. According to Fromm, patriarchal family is one of the most important places where psychological behaviors that continues the existence of class society are formed (Fromm, 2004a: 6, 35).

The compliance of instincts with social reality is the key for the understanding of psychoanalysis. Along with the expansiveness of instincts, prohibiting the cultural satisfaction of instincts unveil some other characteristics: guilt, cowardice, indecision, hesitance, feelings of fearing of a fiasco and being punished (Adler, 2015: 115). Freud regarded the feeling of quilt as the most important problem of culture development, and the price for the development of culture was paid with loss of happiness due to increased feeling of guilt (Freud, 2016g: 153).

Eventually, Freud emphasized that consciousness is a very limited aspect of human reality. Although he developed all his understanding based on this approach, he also emphasized the rationality by stating that "Ego should be wherever id is." Freud praises civilization and defends ego against instincts. Although he examined civilization as a systematical neurosis, a whole of symptoms, repression and sublimation in his book named "Civilization and its Discontents," he considered civilization as a victory human won against their instincts. In this respect, Freud is a follower of social contact approach which regards civilization as an obligatory compromise, and states that the wish for civilization will make people find happiness (Şensoy, 2015: 1).

\section{Repressed Emotions and Neurosis}

Repression is a psychological process that prevents an individual from feeling overly anxious or guilty for feeling desires, ideas or memories which are unacceptable or dangerous to express. 
However, repressed impulses have the power to influence behavior and thoughts as an unconscious source (Karakelle, 2019: 73). Sometimes, they affect our systems of thinking, actions, and decisions without us knowing. We act without even knowing why and can't see that the underlying reason is in the subconscious, which, however, makes us open to a number of guidance of people who solve the common behavior patterns in the subconscious. "People's minds, instincts and impulses that come from their nature become objects and tools that are used for the interests of someone" (Övür, 2016: 34).

Id consists of unconscious desires and impulses that constantly seek satisfaction. At the center of the energy of id lies two basic motives which are sexuality and aggression that ensure the sustainability of life. Therefore, id produces the basic energy that enables us to satisfy our desires so that we can exist. However, id operates according to the pleasure principle. In other words, it demands immediate satisfaction and pain avoidance regardless of the cost of the desires and needs. On the other hand, the Superego is a conscious system of rules, norms, values and ideals which are not innate, acquired through the social environment and which one is exposed through behavior of the parents in the first years of life and so on. Superego tells us what's right and what's wrong. That is, the superego reflects those that are not socially welcome or are not personally correct. Ego, on the other hand, is a balancing system that produces solutions which meet the demands of both in the conflict between id and superego. That is, it consists of logical options that delay the satisfaction of desires or produce appropriate ways to resolve them until a safe and successful solution is found in the present situation. Sometimes it is necessary to repress the id in order to reach a compromise between the id and the superego. Thus, violent desires are pushed to the unconscious (Karakelle, 2019: 73).

Instinct and resistance struggle with each other and consciousness also has a large share in this which continues until the instinct is repulsed and deprived of energy investment. This is the normal solution. However, in neurosis the struggle finds another way out - for yet unknown reasons -. From the very first friction with the instinctive excitement rejected and fired, the self withdraws in some way and prevents it from reaching consciousness and indirect kinetic discharge. However, the excitement fully preserves its energetic investment power during this process. Freud called this process suppression. Undoubtedly, this process represents a primitive defense mechanism comparable to an attempted escape and leads the normal solution which would then be realized through reasoning. This initial act of suppression depends on a number of other consequences. First, the self must protect itself against the suppressed excitement that is always ready to come out and for this, it has to make continuous efforts and a counter-investment; which weakens and impoverishes it. On the other hand, the "suppressed", which is now in the subconscious, is also having a change of bed and - by detour seeking new gratifications to replace the old; thus, it may seek the possibility of frustrating the purpose of suppressing (Freud, 1984: 30-31).

The substitution phenomena resulting from the repression of instincts refer to neurotic disease, more precisely, what we call psychoneurosis. According to Freud, our experience has shown that in most people there is a limit to which their structure can meet the expectations of civilization. Anyone who wishes to be higher-minded than their structure allows will be the victim of neurosis; if they were less good, they would be healthier (Freud, 2007a: 40-41). What is observed as an uneasy impulse for non-stop perfection in some minority individuals must inevitably be understood as the result of impulse repression on which the most valuable products of human culture are based. The process of the formation of neurotic phobia, which is nothing but an effort to escape the satisfaction of an impulse, provides us with a good example of where this "impulse for perfection", which cannot be attributed to all human individuals, originates from (Freud, 2016b: 52).

Symptoms of neurosis are compensatory (spare) satisfactions that have largely substituted unfulfilled sexual desires (Freud, 2016g: 159). The accumulated libido bursts and reaches the point of finding a neurotic substitute satisfaction in the form of pathological symptoms. Anyone who understands the components of neurotic disease will, in a short time, understand that its increase in our society is due to the aggravation of sexual restrictions (Freud, 2007a: 43). According to Freud, society cannot claim to have made a profit at the expense of self-sacrifice when it pays the price of complying with its wide-ranging regulations with increases in neurotic diseases; in fact, it cannot even claim a profit (Freud, 2007a: 52). According to Freud, it is easy to predict the consequences of further restriction of sexual freedom and raising the expectations of civilization to a stage that prohibits all forms of sexual activity other than legitimate marriage. The number of strong structures that openly 
oppose the expectations of civilization will increase greatly and on the other hand the number of weak ones escaping to neurotic diseases when confronted with the conflict between the resistance in their structures with the oppression of cultural influences will increase (Freud, 2007a: 42).

Neurosis is some kind of monastery in which people who are disappointed by life or feel too weak for life in our age are closed (Freud, 2018: 83). The neurotic always acts according to the logic. She/he starts work by avoiding society, puts all kinds of restrictions on himself, interrupts her/his education and work (e.g. headache, muscle pain); paints the future with the darkest colors and secretly stores (Adler, 2015: 117). The neurotic is destined to leave behind the real uncertainty in the search for security (Adler, 2015: 118).

According to Freud, it cannot be overlooking that neuroses originate from experiences related to early childhood and these are experiences that could not be overcome normally, therefore we must inevitably conclude that a neurosis would not have developed without these experiences (Freud, 2015: 124). In the etiology of neuroses, we define the events that we attach great importance to which are experienced first and are forgotten afterwards (Freud, 2015: 124). The concept of trauma is used to name all kinds of events that unsettle, hurt and injure the mental and physical existence of the individual in many different ways (Kokurcan \& Özsan, 2012: 20). We define the non-satisfaction of an instinct as frustration, the power causing it as prohibition and the situation caused by the prohibition as abstinence (Freud, 2017a: 33). According to Freud, who considers the forgetting and rejection of uncomfortable and painful memories usual; even in the case of people who are completely healthy and not suffering from neurosis, there are many indications that there is a resistance against remembering disturbing impressions and developing disturbing thoughts (Freud, 2014: 161). Everything that was forgotten was sad, scary, painful or embarrassing in terms of the aspirations and claims of the personality. For this, all the forgotten were forgotten; they were not conscious (Freud, 1984: 30).

The doctrines about the great causal role played by sexual life and the importance of childhood experiences in resisting, repressing, unconscious and the emergence of neuroses are the cornerstones of the psychoanalysis structure (Freud, 2016f: 127). Most people who went to the psychoanalyst were not ill in the traditional sense of the word, but had difficulties in living. The difficulties of living were, of course, nothing new. There were always people who do not have selfesteem or feel inferior, cannot find happiness in their marriages, cannot be successful in their work or cannot enjoy their work, and who are unreasonably afraid of other people and so on. These people could ask for help from a friend or someone with common sense - or "live barely" without seeking any help. What was new was that, for the first time, Freud and his school offered a comprehensive theory of personality, the best possible description of the difficulties of living rooted in the personality structure and a hope for change (Fromm, 2006: 70).

The psychological life of the people who we call wild and semi-wild is significant for us because in their psychological life, we find the first well-preserved phase of our own development. If this assumption is true, a comparison between the "primitive human psychology" taught by ethnography and the "psychology of neuroses" taught by psychoanalytic research will reveal many similar points and shed light on the more or less familiar issues (Freud, 2017c: 27). The starting point of Hobbes' ideas about the state is also "natural life". According to him, the period in which people lead natural/wild life - without the state - is far from being a golden age. On the contrary, people lived in hell during this period when the state was not yet there. In the natural conditions of life where people are equal and unlimitedly free, the phrase "Man is wolf to man" (Homo homini lupus) has come true. In such a situation where people are constantly afraid of each other, civilization cannot progress. According to Hobbes, it was necessary to make a contract in order to put an end to this life of hell where people crush each other. With this contract, people put an end to their unlimited freedom; they created the giant person (state) to represent and govern them (Kabakçı, 2019: 38). Similarly, the society also signed a contract, renouncing the endless pleasures offered by instincts and agreed to restrain them for coexistence.

Man has delayed, restricted or referred to other means his sense of pleasure because she/he needed others and in order to survive together. However, that desire for pleasure doesn't go anywhere, it stays there, changes shape, transforms and emerges as neurotic symptoms. Some of them cannot do it and this is called perversion, which is the opposite of neurosis. It's a way of running 
to pleasure. Perversion means arousal and pleasure from objects, assets or actions that are not considered ordinary. Deviance or perversion is generalized, not just used for acts that appear to be aimed for sexual pleasure only. Any action other than the accepted, approved, considered ordinary, lawful, customary ways is called with the same name (Oral, 2019). Pervert characters are the ones who follow the id by disabling the superego, cannot suppress the desires of the id, do not exchange the values, rules, morals and laws with their pleasure.

According to Freud, the emergence of impulses unfamiliar to our moral consciousness appears to resemble something we have previously learned - the fact that dreams can access ideational material that is not present in our waking mind or plays a very small role. For example, according to Benini, in dreams, some of our desires that seem to be repressed and extinct for a while awaken again; our old and buried passions come to life again; things and people we never thought about appear. According to Volkelt, the ideas that enter the waking consciousness almost unnoticed and perhaps never recalled also frequently announce their existence through dreams (Quoted by Freud, 2016c: 142). At a time when Superego is weak, Id finds various ways to fulfill its wishes.

According to Freud, dreams reveal the true nature of the person, even if not the whole nature, and allow us to learn the hidden aspects of the soul. According to Kant, dreams exist not to show us our hidden nature and what we are, but to reveal what can happen if we grow up differently (Quoted by Freud, 2016c: 141, 143). Dreams enjoy symbolism to implicitly represent the hidden thoughts. Symbolism is not specific to dreams, but a typical feature of unconscious thinking and it exists in folklore, popular tales, myths, idioms, wits and aphorisms in a more complete way than in dreams (Freud, 2016d: 96). Some series and media content seem to make efforts to reach ideational material and repressed impulses such as dreams that do not exist in our waking minds or play a very small role.

\section{Character and Content Analyses of Game of Thrones Series}

As seen above, the theory of Freud is based on two instincts: Life and death instincts. "According to Freud, the death instinct is in a relation (and a conflict) with the life instinct and creates the endless dynamism of human spiritualism." (Şensoy, 2015: 1). This is what Game of Thrones series narrates: the war between death and life. The series narrates the story of the living in a battle against the army of dead.

We find the needed pluralism of lives in the world of fiction. We die with the characters whom we identify with; however, we keep them alive and then we are ready to die with another character again (Freud, 2007a: 78). Game of Thrones series presents an almost-uncivilized life in which people live their freedom without a limit, seek for pleasure and are directed by the id. The instincts of death and murder are reflected to be closer. The series shows characters who limitlessly experience their sexual desires and uses references which are related to this primary instincts and uncivilized life.

When examined based on death and murder instincts, it can be seen that most of the main characters in the series have died. These instincts are satisfied thoroughly in each episode. Death of main characters indicates that the death is on the doorstep and it is for everybody. Death of a character whom we identify with or we loved dearly has a shocking effect at first; however, the fact that life still goes on provides comfort.

\begin{tabular}{|c|c|}
\hline $\begin{array}{l}\text { Visery } \\
\text { Targeryan: }\end{array}$ & $\begin{array}{l}\text { Visery Targeryan forced his sister to marry Khal Drogo to get the Iron Throne and } \\
\text { burnt to death as Khal Drogo poured melted gold form his head to toe. }\end{array}$ \\
\hline $\begin{array}{l}\text { Robert } \\
\text { Baratheon: }\end{array}$ & $\begin{array}{l}\text { With the order of Cersei Lannister, soldiers made King Robert, an alcoholic, drink } \\
\text { too much wine during a hunting trip and he got killed by a wild boar. }\end{array}$ \\
\hline 'Ned' Stark: & $\begin{array}{l}\text { Ned Stark, who could be regarded as one of the main characters in the first } \\
\text { episodes, went to King's Landing with the persistence of King Robert Baratheon as } \\
\text { the Hand of the King; however, after Joffrey became the king, he executed him by } \\
\text { cutting off his head. }\end{array}$ \\
\hline $\begin{array}{l}\text { Catelyn } \\
\text { Stark: }\end{array}$ & Catelyn, the wife of Ned Stark, got entrapped and died during the Red Wedding. \\
\hline Robb Stark: & $\begin{array}{l}\text { Rob, a son of Ned Stark, died after he was shot by an arrow and then got stabbed } \\
\text { with a knife in his heart during the Red Wedding. }\end{array}$ \\
\hline
\end{tabular}

DOI NO: 10.7456/ctc_2019_03 


\begin{tabular}{|c|c|}
\hline Khal Drogo: & $\begin{array}{l}\text { Khal Drogo, the King of Dothraki, died because of a sever disease he caught after } \\
\text { Mirri Maz Duur casted a spell. }\end{array}$ \\
\hline $\begin{array}{l}\text { Renly } \\
\text { Baratheon: }\end{array}$ & $\begin{array}{l}\text { Renly, a sibling of Robert and Stannis Baratheon, got killed by the ghost baby of } \\
\text { Stannis and Melisandre. }\end{array}$ \\
\hline $\begin{array}{l}\text { Joffrey } \\
\text { Baratheon: }\end{array}$ & He was poisoned during his wedding with Margaery Tyrell. \\
\hline $\begin{array}{l}\text { Oberyn } \\
\text { Martell: }\end{array}$ & He was killed by "The Mountain" during a war practice by crashing of his head. \\
\hline Ygritte: & $\begin{array}{l}\text { Ygritte, who was from the war band, was killed by Olly during the Castle Black War } \\
\text { by getting shot by an arrow. }\end{array}$ \\
\hline Shae: & $\begin{array}{l}\text { Tyrion Lannister killed Shae by strangling her after he found that she had slept with } \\
\text { his father, Tywin Lannister. }\end{array}$ \\
\hline $\begin{array}{l}\text { Tywin } \\
\text { Lannister: }\end{array}$ & Tywin Lannister got shot by an arrow by his son, Tyrion, while he was peeing. \\
\hline $\begin{array}{l}\text { Shireen } \\
\text { Baratheon: }\end{array}$ & $\begin{array}{l}\text { With the order of his father, Stannis Baratheon, she was burned alive and sacrificed } \\
\text { for the Lord of Light. }\end{array}$ \\
\hline $\begin{array}{l}\text { Selyse } \\
\text { Baratheon: }\end{array}$ & She hung herself after her daughter Shireen was burned alive. \\
\hline $\begin{array}{l}\text { Stannis } \\
\text { Baratheon: }\end{array}$ & $\begin{array}{l}\text { After an unsuccessful attack on Winterfell, he got killed by Brienne of Tarth due to } \\
\text { the crime of killing Renly Baratheon. }\end{array}$ \\
\hline Walder Frey: & $\begin{array}{l}\text { Arya Stark slit Frey's throat, thus, avenged the death of his mother and brother } \\
\text { ordered by Frey during the Red Wedding. }\end{array}$ \\
\hline Hodor: & $\begin{array}{l}\text { He stepped forward to protect Bran and Meera from creatures and got killed by } \\
\text { them. }\end{array}$ \\
\hline Rickon Stark: & He was shot in the back by Ramsoy Bolton, a sadistic character. \\
\hline $\begin{array}{l}\text { Ramsay } \\
\text { Bolton: }\end{array}$ & $\begin{array}{l}\text { Sansa Stark who Ramsay constantly raped and tortured killed him by caging him in } \\
\text { with his monster dogs. }\end{array}$ \\
\hline $\begin{array}{l}\text { Tommen } \\
\text { Baratheon: }\end{array}$ & He committed suicide by jumping off a window. \\
\hline
\end{tabular}

Table 2. Deaths of 20 important characters in the series happen as follows: (url4)

Only the deaths of some of characters who we got to know and learned their features are listed here. Thousands of deaths have occurred in the series. Dying with the characters whom we identify ourselves with satisfies the death instinct. The death of the dad Stark, the most powerful character, whom we identified ourselves with at the beginning shocks the audience at first. However, life goes on and his children transform into the characters whom we identify ourselves with. Nonetheless, they cannot avoid getting killed and tortured in a brutal way. Starks who survived in the end avenge people who made them wrong, thus creating a catharsis on the audience.

Aggression and vengeance tendencies which, according to Freud, we gave up for civilization are the main elements in the series. There are numerous characters who try to take revenge of their families and comfort the audience by doing so in the series. Khaleesi/Daenerys Targaryen has waited for long year to get vengeance for the murder of her father and whole family, and fought to regain the power they had lost and to get revenge. Her succeeding and getting her revenge satisfy our wish to get revenge and comfort us as if it was realized by us. Other than the case of vengeance, Khaleesi represents and canonize matriarchal life.

At one point in history, matriarchal family structure dominated the world; however, with the establishment of social structures, patriarchal system overpowered matriarchy and hit the headlines (Fromm, 2004a: 6). L.H. Morgan's ideas show similarity with the above-mentioned ideas of Bachofen. Morgan claimed that a developed civilization would be based on the principles of freedom, equality and fraternity, and developed a theory which explained such civilization would be formed based on the old concept of original family (Fromm, 2003: 200). Khaleesi who was in the position of a Goddess referring the matriarchal society represents these ages and the oldest order. She takes us to the beginning of the history of civilization. She is an indicator of returning to matriarchal order. Khaleesi frees slaves in the places she captured and tries to set a fair order. She gets uncomfortable with the treatment against women in a village that they invaded. A horseman protests her alternative recommendation and has a one-to-one battle against Drogo. With her increasing power and need for an army, Khaleesi decides to buy the famous slave-army, the Unsullied. Khaleesi raids Astapor with 
her army then frees her army from slavery. The Unsullied does not resign their commitment to her after being set free and they proceed on their way all together. The fearless female character, Khaleesi protects the oppressed ones but she is cruel to oppressors as well. Khaleesi also frees the slaves in Meereen and hangs some of the Supreme Masters (url5). In the finale episode, Khaleesi turns into a dictator that she fought against. Because of her anger and drunkenness of power, she burns down and destroys a city. When she is about to sit on the Iron Throne, she gets killed by the man she fought with and loved, John Snow, considering that she cannot bring a fair order. In this way, Khaleesi who is in the position of a female Goddess gets defeated and Bran Stark who is in the position of a male God, who sees and knows everything, replaces her.

According to Freud, the hunger of people can only satisfy with food, their desire to be loved can only satisfied with the thought of a loving God and their sadistic tendencies can only be satisfied with sadistic images or fantasies (Fromm, 2004a: 56). Game of Thrones series has numerous sadistic elements. The perverted and tormentor character in Game of Thrones series, Ramsay Bolton tortures his victims in a brutal way. Ramsay Bolton used violence on his wife, Sansa and raped her, and tormented Theon Greyjoy (Reek), satisfying the individuals with sadistic tendencies; however, these may trigger the mean world syndrome for other people.

Freud considers castration as the biggest fear of men. Men's fear of castration which Freud often put emphasis on is performed on Reek in the series. Reek's penis is ceased in the series, referring to the castration complex. After Ramsay Bolton tortured Reek by ceasing his genitals, Reek starts to desperately obey his tormentor master. Another character who was also castrated is Lord Varys. An enchanter cut his genitals off completely and threw into fire.

Sadistic behaviors of the perverted character Ramsay Bolton gradually escalate in every episode. In addition to physical damage, he tortures his wife Sansa and Reek by insulting and humiliating them. However, in the end, Ramsay Bolton gets killed by his wife in sadistic way that befits to him. Sansa feeds Ramsay Bolton to dogs who were raised by Ramsay Bolton and were left starving for seven days. Calmness and satisfaction of Sansa, the wife of Ramsay Bolton, on this scene where she avenged upon her husband pass over to the audience. Arya Stark, youngest daughter of Ned Stark, keeps the feeling of revenge by constantly saying over the names of the characters that she will avenge, and in the end, she kills them one by one. In the episode ten, the sadist man, who feel pleasure by beating little girls, cannot get away from Arya's wrath and gets murder brutally.

According to Freud, the obstacle raised against incest might be one of the historical achievements of humanity; however, Game of Thrones series disregards this achievement for the sake of rating. The series has characters who deactivate superego and only go after the desires of id. Lannister siblings are an example for this. The Lannister siblings grew up with a dominant and loveless father. One the Lannister siblings is a dwarf; thus, he sharpened his intelligence just to spite his stagnant body. The other two siblings are pervert characters who are unable to repress their impulses and madly seek for pleasure.

Approaching incest as a normal phenomenon, twin siblings being in love are subjects that are not included in media content and regarded as too hazardous to approach. Two siblings having sex by the corpse of their son is one of the most contradictory scenes in the series. The female sibling, Cersei Lannister has remarkable dialogs on impulses. In one scene, Cersei says the following: "I do not care about restraining my bad impulses." And for her enemy Khaleesi, she says the following: "She chose a consultant who would restrain her worst impulses rather than feeding them. That is the difference between us." After Cersei becomes the queen and seized power, she does not care about other people. In the third episode of season seven, twin siblings do not find it necessary to hide their relationship. When Cersei becomes the queen, declares that her child to be born is from her brother stating that "Lion does not fester about the thoughts of sheep." A comment on this relationship made on a website is also remarkable; "They have the most accepted unsettling relationship. Maybe because of their narcissistic cuteness or maybe because they make right decision when needed, made this relationship accepted among the audience." (url6). This comment supports the fact that media is the most effective factor for making the society accept or reject something, thus, it is important to note that produced contents should be prepared in a very careful way. Contents that normalize and make people accept perverted, pedophilia, sadist, murderer etc. characters by attributing nice features to them and presenting them to be one of us should be watched out. 
Another contradictory and unsettling subject in the series is the father who has sex with his own daughters and forms a clan with them. This primitive character named Craster does not let any other men to get close or talk to his daughters and female grandchildren from his daughters. $\mathrm{He}$ causes his sons from his daughters to die by handing them to dead. Craster lives in one of the stations on the Nightwatcher and cannot stand to any other men to look or touch to his daughters. This character reminds us Josef Fritzl who was defined as the "Monster of Century" on news in the real life. Josef Fritzl is a father from the city Amstetten, Austria who kept his daughter captive for 24 year in the basement and raped her, and had seven children from her. Narrating incest events which recently in Turkey, are brought to agenda with Palu family may damage the obstacle raised against incest and normalize perverted characters.

One of the most important characters in the series is the dwarf Tyrion Lannister. According to Freud, children who do not receive their mothers' compassionate care encounter mental health disorders (Fromm, 2004b: 52). Mother guarantees the lives of her children and her love forms a protection and safety feeling within children. (Fromm, 2004a: 90). Children cannot be certain that their needs will be met when a mother is not around and withholds her love, thus, making children feel anxious (Freud, 2017b: 115). When examining the Lannister family, all three children never met their mothers and grew up with a dominant father devoid of mother's love. The mother of the Lannister siblings died during the birth of Tyrion Lannister. Tyrion Lannister lived with the feeling of quilt and was excluded by his two siblings. The effects of living without love under a strict authority can be seen on Tyrion Lannister. Tyrion Lannister has a sad and alcoholic identity. The father Lannister symbolizes patriarchal life. He has a strict and authoritative character, and cares about success; thus, focuses on his children based on his expectations. What his children want does not matter. He ignores and humiliates Tyrion Lannister who does not meet his standards.

In patriarchal societies, sons surrender to the desires of their fathers. The destiny of sons who are regarded as the property of their fathers is also determined by their fathers. Children must comply with their father and put their fathers' desires over their own thoughts and desires to have a right on their father's heritage and replace him (which indicate success). Similar to any kind of repression, this kind of repression may turn into hatred and the desire to save oneself form the oppressor and in the end to kill them (Fromm, 2004b: 55). Tyrion Lannister shoots his father, who tyrannized and humiliated him for years and lastly slept with the women he loved, with an arrow and kills him while he is in toilet. Another instance of the transformation of the conflict between the father and son, and inheritance dispute into hatred is Ramsay Bolton. Ramsey Bolton, who is already a perverted character, congratulates his father when he learns that his father will have another son and then kills him by stabbing him on his abdomen.

The series also includes characters who presents excessive love and intimacy between mother and son. Lysa Arryn is mother who breastfeeds her 11-year-old son and who is excessively attached to him. Lysa Arryn is the unhealthy sister of Catelyn Stark and keeps her son close by thinking that in this way she can protect him. The bizarre relationship between Lysa Arryn and her son is ranked as one of the most shocking 20 scenes on a website (url7). According to Freud, narcissism dominates breastfeeding babies and these babies only care the satisfaction of their needs and desires. Towards the end of nutrition period, the second phase where babies develop sadistic or hostile attitudes towards objects follows up (Fromm, 2004a: 88). Robin Arryn, the son of Lysa Arryn, is an unhealthy, grouchy, spoiled and narcissist character with sadistic tendencies.

Sexuality element which Freud includes among life instincts is largely used in the series with the thought of "sex sells." In addition to homosexual relationships, the series refers to sexuality instinct through various fantasies including groups and sadistic elements. In the fifth season, with spread of religion element among the society, we can see that people who do not comply with sexual prohibitions and rules are punished. In the seventh episode of season five, religionists attack to a brothel run by a powerful politician and burn it down. Owner of the brothel talks about his success on the generation of desire by stating the followings; "various desires and needs have been met in here. It was a place of desires which did not exist until we found them."

Media contents change in this era where narcissism, speed, power and egocentrism dominate. While old films and series mostly used contents intended for superego, today's contents mostly prompt id and its desires. This does not only apply to series, but also apply to other media 
contents such as digital games, advertisements. Superego has turned into an excessively domineering structure in some societies, thus, may affecting this situation. However, it is apparent that the main reason is the media producers who have discovered the power of subconscious on behaviors. Individuals who watch presentations intended for id and the needs and desires of id enjoy and prefer these contents without knowing.

\section{Conclusion}

People turn to objects and people who satisfaction their abstinence, meet their need, satisfy their hunger and develop dependence on them. From the satisfaction of biological needs ranging from the need for food to psychological needs (the needs of the age such as entertainment, being liked, narcissism, instincts such as violence, sexuality, etc.), if something satisfies an abstinence or need, one will depend on it and maintain the relationship. Her/his interest in products that do not satisfy any need will be reduced. In Jim Carry's Kidding series, for example, there are numerous references to childhood traumas, and psychological content is widely used. Considering that everyone has childhood traumas, it attracts the attention of the audience and is likes because it provides identification.

In the series like Game of Thrones, the most hidden and inappropriate behaviors are revealed and people are satisfied by removing the inhibition, which in turn provides the producers with rating. But what effects will this content aimed at impulses will have? This needs to be considered. As in the theory of offensive examples or the increase in suicides after the publication of suicide news, will the audience actually try to implement these activities and bring them to real life? Or will it experience only a catharsis, as in the purification theory? Or will it become more and more connected to the virtual world by escaping from reality and believing that this world is very cruel and impossible to live in, as in mean world syndrome?

Just as neurosis is a monastery in which people who are disappointed and feel too weak for life are closed, the virtual world is a similar monastery for many people. We seek the repair or compensation of our frustrations in the means of communication and use fantasies in the virtual world to repair them. We find compensation by identifying with the powerful characters of the virtual world, and feel relieved by seeing the identical characters that experience what we experience, feel what we feel and do what we have to do.

According to Freud, "The person we call crazy is the one who dreams when she/he is awake" (Freud, 2017b: 7) however, today people prefer to have a "technological dream" instead of waking up due to difficult living conditions. In this age where virtual and reality are intertwined, people who are in digital ecstatic state, lingering with contemporary fantasies and daydreams are all around us, reality is influenced by the virtual and vice versa. We can see the effects and reflections of the virtual world in current events. Some digital games, such as the Blue Whale, do not remain only in the virtual world, they want to make the transition to reality and remind us of Baudrillard's hyperreality theory. According to Baudrillard, from now on, only a hyperreality which lacks any imaginary and real distinction and consists only of models with a repeatable trajectory and production of difference simulation can be discussed (Baudrillard, 1998a: 13). But will the images reflected from a terrorist's camera in the New Zealand mosque attack only remain as a portrayal of the "Call of Duty" game? Or will we see new hyperrealities that have sprung from the virtual world into the real world?

Especially in new media, which holds an important place in the self-construction of young people, will civilization not be sought in order to experience unlimited liberation and satisfaction in the virtual world? Will there be no ethical rules? Will we live an unrestricted wild life? Will people be free in the virtual world with their holograms or virtual personalities? But what effect will that world have on the real world? This is one of the issues that should be considered from a sociological perspective. Maybe they will come to the point of completely breaking away from the real world with the satisfaction they will find in that free world or they will try to carry what they have experienced in that world to this world.

Game of Thrones opens the doors to a free but non-civilized world where the promised freedom is endless and instincts are not repressed as in Freud's famous words "Freedom is not a gift of civilization to man. Humanity was much freer when there was no civilization." (url8) However, it 
should not be forgotten that even the right to live, which is the most natural right, is not guaranteed in the wild life and a certain order and mechanism is necessary to live collectively. The obligation of obeying these rules to live together brings sacrifices from some freedoms, but it is necessary to obey the civilization contract for contemporary civilization.

It is seen that people are looking for satisfaction for their various instincts and hidden thoughts with new media. The givers/sources who are aware of this, know the target audience well and know/study their psychological characteristics are also able to reach their high audience affect the target audience spot-on by creating their messages based on these emotions and reach greater audiences. However, it should be remembered that the repression of instincts is important for civilization. They may provide individual relief but it should be remembered that in the long run, revealing these instincts will lead to undesirable consequences and shake the pillars of civilization and lead to conflicts. Revealing the emotions that need to be repressed for the sake of rating can unsettle the civilization contract of societies.

It is also not right to think that "this is in my instincts" or "this is natural". And, it should not be seen as a justification for the violent events or perversion that we experience today. It is stated that it is necessary to overcome these instincts and energies by transferring them to other positive features as a necessity of living together. On the contrary, it is emphasized that it is necessary to think about the negative effects of discussing them and displaying them in media content.

\section{References}

[1] Adler, A. (2015). Bireysel Psikoloji. 4. Basım. A. Kılıçoğlu (çev.). İstanbul: Say Yayınları.

[2] Baudrillard, J. (1998a). Simülakrlar ve Simülasyon. Birinci Baskı. O. Adanır (çev.). İzmir: Dokuz Eylül Yayınları.

[3] Freud, S. (1984). Freud: Yaşamım ve Psikalaniz. Özyaşam ve Anılar Dizisi: 1. A. Tokatı (çev.). Kardeşler Basımevi. İstanbul: Düşün Yayınevi.

[4] Freud, S. (2000). Metapsikoloji. 1. Basım. A. Yardımlı (çev.). İstanbul: İdea Yayınevi.

[5] Freud, S. (2007a). Uygarlık, Din ve Toplum. 6. Basım. S. Budak (çev.). İstanbul: Öteki Yayınevi.

[6] Freud, S. (2007b). Psikanalize Yeni Giriş Dersleri. 6. Basım. S. Budak (çev.). İstanbul: Öteki Yayınevi.

[7] Freud, S. (2014). Günlük Yaşamın Psikopatolojisi. 1. Basım. H. Can (çev.). Ankara: Tutku Yayınevi.

[8] Freud, S. (2015). Musa ve Tektanrıcılık. 1. Basım. K. Şipal (çev.). İstanbul: Say Yayınları.

[9] Freud, S. (2016a). Nevrozlar. 2. Basım. K. Şipal (çev.). İstanbul: Say Yayınları.

[10] Freud, S. (2016b). Haz İlkesinin Ötesinde Ben ve İd. 5. Basım. S. Babaoğlu (çev.). İstanbul: Metis Yayınları.

[11] Freud, S. (2016c). Rüyaların Yorumu 1. 3. Basım. S. Budak (çev.). İstanbul: Öteki Yayınevi.

[12] Freud, S. (2016d). Rüyaların Yorumu 2. 2. Basım. S. Budak (çev.). İstanbul: Öteki Yayınevi.

[13] Freud, S. (2016e). Cinsellik Üzerine Üç Deneme. 4. Basım. S. Budak (çev.). İstanbul: Öteki Yayınevi.

[14] Freud, S. (2016f). Yaşamım ve Psikalaniz. 12. Basım. K. Şipal (çev.). İstanbul: Say Yayınları.

[15] Freud, S. (2016g). Kültürdeki Huzursuzluk. 2. Basım. V. Atayman (çev.). İstanbul: Say Yayınları.

[16] Freud, S. (2017a). Bir Yanılsamanın Geleceği. 1. Basım. K. Şipal (çev.). İstanbul: Say Yayınları.

[17] Freud, S. (2017b). Mutluluk Dediğimiz Şey. 6. Basım. P. Demirel (çev.). İstanbul: Aylak Adam Yayınları.

[18] Freud, S. (2017c). Totem ve Tabu. 4. Basım. K. Şipal (çev.). İstanbul: Say Yayınları.

[19] Freud, S. (2017d). Bir Histeri Vakası Analizi. 2. Basım. G. Topuz (çev.). Ankara: Alter Yayınları.

[20] Freud, S. (2018). Psikanaliz Üzerine Beş Konferans ve Psikanalize Toplu Bakış. 2. Basım. K. Şipal (çev.). İstanbul: Say Yayınları.

[21] Fromm, E. (2003). Rüyalar Masallar Mitoslar. Birinci Baskı. A. Arıtan ve K. H. Ökten (çev.). İstanbul: Arıtan Yayınevi.

[22] Fromm, E. (2004a). Anaerkil Toplum ve Kadın Hakları. Birinci Baskı. A. Doğangün (çev.). İstanbul: Arıtan Yayınevi. 
[23] Fromm, E. (2004b). Freud Düşüncesinin Büyüklüğü ve Sınırları. 1. Basım. A. Arıtan (çev.). İstanbul: Arıtan Yayınevi.

[24] Fromm, E. (2006). Psikanaliz ve Din. 1. Basım. E. Erten (çev.). İstanbul: Say Yayınları.

[25] Fuchs C. (2016). Sosyal Medya: Eleştirel Bir Giriş.1. Basım. I. Kalaycı ve D. Saraçoğlu (çev.). Ankara: NotaBene Yayınları.

[26] Kabakçı, E. (2019). Siyasal Düşünceler Tarihi. İstanbul Üniversitesi Açık ve Uzaktan Eğitim Fakültesi. Sosyoloji Bölümü 1. Sınıf. Güz Dönemi Ders Notları.

[27] Karakelle, Ş.S. (2019). Psikolojiye Giriş II. İstanbul Üniversitesi Açık ve Uzaktan Eğitim Fakültesi. Sosyoloji Bölümü 1. Sınıf. Bahar Dönemi Ders Notları.

[28] Koç, N. E. (2018). Şiddet İçerikli Dizilerin Popülarite Sebepleri. e-Journal of New Media / Yeni Medya Elektronik Dergi - eJNM ISSN: 2548-0200, January 2018 Volume 2 Issue 1, p.26-36.

[29] Kokurcan, A. ve Özsan H. H . (2012). Travma kavramının psikiyatri tarihindeki seyri. Kriz Dergisi, 20 (1), 19-24. Retrieved from http://dergipark.gov.tr/kriz/issue/41037/496016

[30] Oral, G. (2019). Sapkınlık Üzerine. İstanbul Aydın Üniversitesi 4. Psikoloji Günleri. Konuşmamız Lazım. Prof. S. Gökhan Oral'ın yaptığı konuşma. 15 Mart 2019.

[31] Ormanlı, O. (2012). Yeni Medya ve Türk Sineması. Deniz Yengin (Ed.). Yeni Medya Ve içinde. (339-363). İstanbul: Anahtar Kitaplar Yayınevi.

[32] Şensoy, B. Ö. (2015). Freud'un Teorisinde Ölümün ve Ölümlülüğün Yeri: Bir Giriş. https://www.academia.edu/1997669/

[33] Yengin, D. (2015). Yeni Medyada Boş Zamanın Dönüşümü: Tıkınmalı İzleme. Deniz Yengin (Ed.). Sosyal Medya Araştırmaları içinde. (s. 211-257). İstanbul: Paloma Yayıncılık.

[34] Yılmaz, S. (2013). Çocuklarda 'Ölüm Kaygısı'nın Çeşitli Değişkenler Açısından İncelenmesi. Bilimname, 25(2), 2013/2, 169-189.

\section{Online References:}

[38] url1:https://www.ntv.com.tr/galeri/sanat/game-of-thronestan-bir-rekor-daha,tXx_PamXeUKmYnAd2VrSA/w8eiy8A_qEu1kz-A6DqKvg

[39] url2: https://onedio.com/haber/meraklisi-icin-game-of-thrones-rehberi-282701

[40] url3: https://paratic.com/game-of-thrones-dizisi/

[37] url4: https://www.cnnturk.com/magazin/dizi/game-of-thronesta-simdiye-kadar-olenkarakterler?page $=1$

[42] url5: https://gameofthrones.fandom.com/tr/wiki/Daenerys_Targaryen

[43] url6: https://noluyo.tv/haber/4210/game-of-thronesun-pek-tasvip-etmedigimiz-iliskileri/

[41] url7: https://hthayat.haberturk.com/yasam/kultur-sanat/haber/1034805-game-of-thronesun-ensok-edici-20-sahnesi/19

[35] url8:https://dusunbil.com/bilincdisina-giden-karanlik-yolun-izlerini-arayanfreuddan-11-alinti/ 